\title{
WATER AS A WEAPON OF WAR IN THE TIGRIS-EUPHRATES BASIN
}

The current world is more interconnected with hybrid international relations. Therefore, diplomacy should be more flexible with new tools and able to face current global challenges. Furthermore, over 90 percent of the world population is in the transboundary basin. According to the UN (UNWATER, 2018), the top challenges are associated with water, like among other things climate change, water shortages, and water pollution. In some cases, island countries can disappear due to rising sea levels. In our Blue Planet, it is predicted that by $203050 \%$ of its habitats will have experience water shortages and in 2050, in the oceans, we will have more trash than fish. From Asia and Africa, we will experience massive migration (25-700 million people) searching for drinking water. At the same time, there will be a serious scarcity water risk in megacities, like Moscow, Mexico City, Beijing, Cairo, London, Miami and the other 500 largest cities in the world. By 2050 it is expected that on our planet there will be 9 billion people, of which more than two-thirds will be living in cities. Therefore, we need water diplomacy as a kind of modern multi-track diplomatic effort with a large platform for global cooperation on water. Water diplomacy contains various types of diplomacies with many strategies and innovative approaches; it seeks to resolve economic, conflict prevention and resolution, shuttle, science, migration, and public interests. The cooperation network should include multi-level actors, including governments, international organizations, military community, local authorities and its leaders, NGO's, and private entities.

The international community must recognize the vital significance of water for sustaining international peace and security (UN, 2018). The role and significance of control of water resources are growing very fast. It is crucial for states to survive as well as geopolitics and foreign, security and defence strategies. The water has been a political and military tool as well as a weapon for terrorism. The scope of this research is the Middle East because this region is important for emerging global security architecture and water issue in this region is an extremely important element for national interests and strategies.

This research paper presents the basin of the Tigris and Euphrates, in which water is one of the most important tools for waging war. Therefore, in May 2014, the United Nations declared that water is used as a "weapon of war in military conflicts" (Deen, 2014). The research problem undertaken is extremely important because it touches upon the foundations of human existence on our planet. The Tigris and Euphrates basin, like 4,500 years ago is the focal point. Currently, in the 21 st century, the Twin Riv- 
ers becomes essential for the global security structure. The paper aims to present water as a weapon of war in the Tigris-Euphrates Basin, as well as the role and significance of water for a new architecture of global security.

The main goal of the study is to find an answer to the research question of whether water the Tigris-Euphrates basin will be still a tool for fighting or cooperation as an effective tool for facing strategic challenges? The research hypothesis is that the issue of challenges related to water in the Euphrates River basin will, first of all, follow the social and political-economic relations between Turkey, Iraq and Syria and external factors. Therefore, without international coordination and far-reaching strategy in the face of the emerging anarchic global security structure, stable water cooperation in this region cannot be reached.

Although there is already a quite large basis of literature related to the Euphrates River basin, presenting water as a war weapon, as well as linking it with water diplomacy and the new emerging architecture of global security expands knowledge about this problem. Considering the current knowledge and literature of the subject, very interesting are analyses by Aaron Wolf from the Oregon State University, especially related to water resources policy and conflict resolution, and dr. Susanne Schmeier, a specialist in water law from IHE Delft Institute for Water Education. An interesting study conducted by the Stockholm International Water Institute (SIWI) is prepared Strategy 2018-2021. Worth mentioning is also the Water Diplomacy Workshop conducted by the Program on Negotiation at Harvard Law School and the Water Diplomacy Program of Tufts University and its director Professor Shafiqul Islam's publications. For special attention deserves Larry Susskind book, Water Diplomacy: A Negotiated Approach to Managing Complex Water Networks, New York 2013. For analysing water diplomacy policymakers should be recognise the Hague Institute, which has a large consortium partners, including UNESCO Category II Centre on International Water Cooperation, the Stockholm International Water Institute (SIWI), Uppsala University, Tufts University, IUCN Asia, Helmholtz Centre, the Clingendael, and the Hague Institute for Global Justice. The Institute builds an innovative approach to multi-track water diplomacy. The Hague Institute has underlined emerging water conflicts and it identifies tools for preventing or resolving the water crisis.

The research was conducted using a descriptive-analytical method. The researcher analysed source materials, research materials on the subject, as well as observations of personal diplomatic activities in multilateral fora. Besides, a wide range of theoretical instruments is used to investigate this issue, to analyse the problem in the multilevel approach to international relations. Moreover, this research is based on the neorealist theory of international relations, and the concept of international constellation analysis. On the other hand, the theory of neo-institutionalism allowed for the precise mythologisation of general and specific functions of international security institutions. Even though the constructivist theory is primarily based on national constellations, it ascribes even more significance to international institutions and their supernationally anchored norms and ideas than the rational institutionalism does. For that reason, it was also taken into consideration. In these analyses, the school of the social constructivism theory was also utilized. 


\section{THE MIDDLE EAST AND THE TIGRIS-EUPHRATES BASIN}

The Middle East is a place where the risk of conflict is higher than anywhere else. Presented by politicians and the media as ethnic, religious or territorial conflicts, these are often invisible to us. The water scarcity, as well as the construction of dams and canals, are threats for international security. The current most important war with terrorism is located in the Tigris-Euphrates basin. The reason is the lack of drinking water, permanent mosaic of political conflicts and social, environmental or economic challenges. To show a wide range of challenges in the context of water, The Tigris and Euphrates basin, in which Turkey, Syria, and Iraq are located, is a very good example for scientific analysis. In the second half of the 20th century, many conflicts took place in the Tigris and Euphrates basin. The 21st century began with unprecedented cooperation between Turkey, Syria, and Iraq. In 2003, following the invasion of Iraq by the US, despite the establishment of an autonomous Kurdish region with the capital of Erbil in northern Iraq, Turkey quickly took priority in its foreign and security policy to improve relations with its neighbours and to create a stable environment in the region. An important reason for such a policy was the fact of negotiations with the EU regarding the "energy corridor" through Turkey, which was a priority for it, aimed at increasing the role and significance of Turkey both in the region and for Europe. This, in turn, was

\section{Map 1. Map of Tigris-Euphrates Basin}

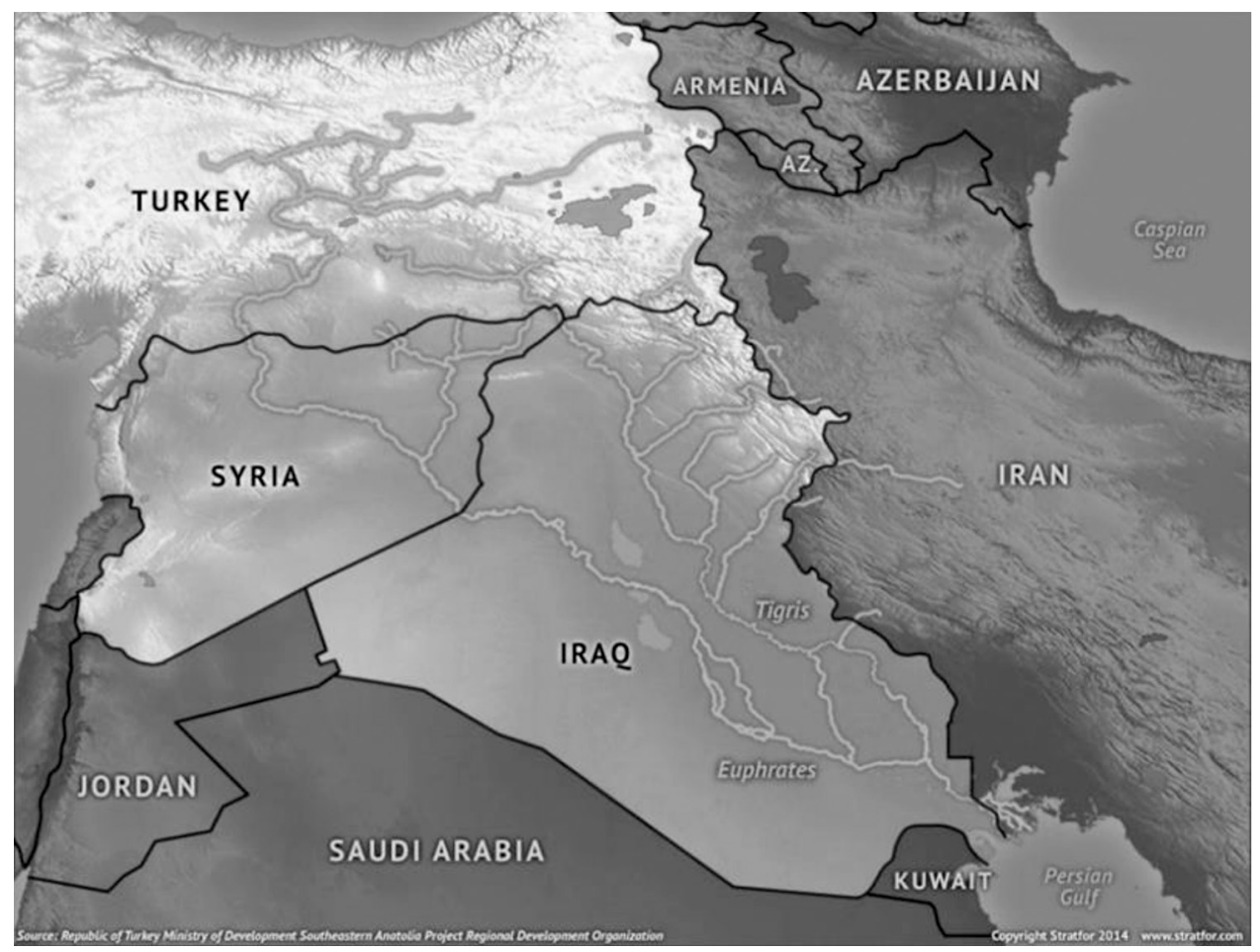

Source: http://www.waterpolitics.com/2015/01/05/3279/. 
in line with the "strategic depth" doctrine of the Justice and Development Party (AKP), implemented by Ahmet Davutoğlu, former foreign minister and then prime minister of Turkey. It assumed the use of Turkey's geographical location to give it the rank of the main energy corridor on the east-west route. In particular, supplying energy carriers mainly from the Caspian basin, Iran and Iraq (Handy, 2011: 66). In Syria, the US invasion of Iraq brought anti-Western sentiments. At the same time, Syria maintained its efforts to conduct correct relations. This cooperation took place despite many challenges, such as one of the largest in the history of drought Tigris-Euphrates Basin or the war in Iraq and political upheavals in this country. Besides, in 2005, scientists and experts from Turkey, Syria, Iraq and the United States set up a cooperation platform for the Euphrates Tigris Initiative for Cooperation (Wasinger, 2015: 52).

In the years 2000-2009, Turkey, Iraq, and Syria experienced the dynamic work of the permanent Joint Technical Committee. Also, in 2008 Turkey and Iraq have established a High-Level Strategic Cooperation Council (HSCC), consisting of diplomats from both countries to establish closer water and agricultural cooperation. In 2009, Turkey created a similar council with Syria (Kibaroglu, 2015). Moreover, Turkey in 2009 signed with Iraq Memorandum of Understanding (MoU) on Water focuses on sharing hydrological and meteorological information (Kibaroglu, 2017: 15) as well as with Syria MoU concerning the construction of the joint Orontes River Friendship Dam (Scheumann, Shamaly, 2016: 125-126).

In the years 2003-2009, the Tigris-Euphrates basin lost 117 million acre-feet of stored freshwater, which is the second fastest loss of water in this period in the world. In south-eastern Turkey, arable fields have dried up. In Iraq, drought and sandstorms resulted in a 51 percent drop in harvest, and two million people in the south of the country faced a shortage of drinking water and electricity. In Syria, the harvest was lower by 38 percent, as a result of which 800,000 people lost their livelihoods, and by 2010, 160 villages in Syria were abandoned (Wasinger, 2015: 79-80).

2011 started very well for water cooperation. In January, Turkey, in cooperation with its neighbours, Iraq, Syria, Iran, Georgia, Bulgaria and Greece, announced a plan to build 18 cross-border dams. In February, Turkey started the construction of a dam on the Orontes River, which Syria was interested in. However, as early as in March, a revolution began in Syria, which brought catastrophic consequences for water cooperation in the Tigris-Euphrates Basin. By the end of June 2014, Turkey completely closed the gates of the dam, for the first time, reducing the flow of the Euphrates to Syria. However, the water relations between Syria and Iraq remained generally unchanged. On the other hand, the hydro-political relations between Turkey and Iraq have some break because of the differences between the views of the Turkish leader and the new Shi'ite regime in Iraq (Wasinger, 2015: 95).

One of the biggest challenges for regional, as well as global security architecture, is a water scarcity in the Middle East. The dry climate of the Middle East and limited water sources pushes the states and non-states players there to compete for control over them. Tensions and conflicts over the resources of all major international rivers are continuing. Analysing the armed conflicts of recent years, it should be stated that what is more often used as a weapon is water and its infrastructure, including through its control, destruction, or water poisoning. Many examples are reported by the Pacific 
Institute. For example, in 2018 in Basra, Iraq, tens of thousands of people became seriously ill due to water pollution. In 2016 alone, Syria's access to drinking water decreased by 50 per cent. The reason was deliberate attacks on water infrastructure. However, in the same year in Iraq, fighters of the so-called Islamic State destroyed the water pipeline leading to eastern Mosul and depriving water of half a million inhabitants. There could also be many examples in other regions of the world. In 2018, in the Oromia Ethiopia region, 76 water systems were damaged during conflicts, resulting in hundreds of thousands of people fleeing. In Europe, in the Ukrainian Donetsk, the water filter station and its staff were deliberately shelled, which caused disruptions in the water supply for 350,000 inhabitants (Pacific Institute, 2019). Besides, these means of struggle apply to both non-state participants in wars and the state. However, victims are almost always civilians. The use of water for military purposes is most often found in the Middle East (Strategic Foresight, 2019).

From 2011 on the situation in the Tigris and Euphrates basins, apart from changes in the hydro-politics of Turkey, Syria and Iraq, the greatest impact was exerted by rapidly gaining non-state actors, such as the fighters of the Kurdistan Worker's Party (PKK), Free Syrian Army (FSA), Front al-Nusra, the Kurdish Regional Government (KRG), Kurdish Peshmerga and other. However, the most destructive actions in the Tigris Euphrates basin, using water for military actions, were shown by the so-called Islamic State in Iraq and Syria (ISIS, Daesh). Water for Daesh became one of the basic weapons, controlling the twin Mesopotamian rivers and strategic, its critical infrastructure. It has become central to military actions successes. Daesh moved in Iraq and Syria first of all along the Tigris and Euphrates rivers. In the Daesh armed forces strategy, the most important goals were control over the cities and dams of the rivers. An example of this is the closure of the massive gates of the Iraqi Fallujah dam in April 2014. The result of this action was flooding 200 square miles of farmland and villages, destroying homes and destroying crops, as a result of which Iraq forces withdrew and Daesh captured Fallujah (Wasinger, 2015: 97-98).

Since 2011, the water, as well as its infrastructure has been the tool or the target of numerous Daesh attacks. Below it is presented a list of only the most important events related to water infrastructure in the period 2011-2018.

Table 1

Water Conflict in Tigris-Euphrates Basin

\begin{tabular}{||c|l||}
\hline Date & \multicolumn{1}{c|}{ Description } \\
\hline 1 & \multicolumn{1}{c|}{2} \\
\hline 2018 & $\begin{array}{l}\text { Tens of thousands admitted to hospitals from contaminated drinking water, inciting vio- } \\
\text { lence that leads to deaths and injuries } \\
\text { Tens of thousands fall ill from contaminated drinking water in Basra, Iraq. In response, citizen } \\
\text { unrest escalates and protests turn violent, leaving at least 15 dead and hundreds injured. }\end{array}$ \\
\hline 2018 & $\begin{array}{l}\text { Iraqi female activist assassinated } \\
\text { An Iraqi activist, Soad Al-Ali, is assassinated while getting into her vehicle in Basra, Iraq. Mrs. } \\
\text { Al-Ali had worked to bring better government services to her community, including safe and } \\
\text { reliable drinking water. }\end{array}$ \\
\hline 2018 & $\begin{array}{l}\text { Major dam and water source captured in Syria } \\
\text { The Afrin Dam, a major dam and water source on the Afrin River in Syria, is captured by Turkish } \\
\text { forces and their Syrian militia allies, causing concern for the nearby communities that depend on }\end{array}$ \\
\hline
\end{tabular}




\begin{tabular}{|c|c|}
\hline 1 & 2 \\
\hline & $\begin{array}{l}\text { e dam for water. These same forces are also in control of nearby Maydanki dam. Interruptions } \\
\text { water and electricity in communities dependent on these dams have occurred, along with re- } \\
\text { orts of attacks on civilian centres and populations. }\end{array}$ \\
\hline 2017 & $\begin{array}{l}\text { Islamic State is accused of cutting off water to a village by diverting a river } \\
\text { A group identified as the Islamic State is accused of cutting off the water flow to a village by } \\
\text { diverting a river in Abu Karmah, Muqdadiyah, Diyala, Iraq. }\end{array}$ \\
\hline 2017 & $\begin{array}{l}\text { Conflict over water quotas lead to two deaths in Iraq } \\
\text { Conflict arises between two tribes over water quotas, leaing to two deaths and eight injuries in } \\
\text { Suq Al-Shoyokh, Thi-Qar, Iraq }\end{array}$ \\
\hline 2017 & $\begin{array}{l}\text { ISIS floods villages in the Deir Hafer Plain of east Aleppo } \\
\text { In response to the advance of the Syrian Arab Army, The Islamic State (ISIS) floods villages } \\
\text { they control in the Deir Hafer Plain of east Aleppo by pumping water from Lake Assad into the } \\
\text { Al-Jar channel. }\end{array}$ \\
\hline 2016 & $\begin{array}{l}\text { Intentional attacks on water infrastructure } \\
\text { Control over power and water infrastructure and intentional attacks on that infrastructure are } \\
\text { being used as weapons in the civil war in Syria. Officials estimate there has been a } 50 \text { percent } \\
\text { reduction in access to safe water in the country since the war began. }\end{array}$ \\
\hline 2016 & $\begin{array}{l}\text { Islamic State fighters destroy pipeline that provid } \\
\text { Islamic State fighters cut electricity to pumping statio } \\
\text { ter for eastern Mosul, Iraq, leaving more than half a n } \\
\text { intentionally cut off water supplies to various neighbo } \\
\text { official responsible for supervising the city's water an }\end{array}$ \\
\hline $\begin{array}{l}2015- \\
2016\end{array}$ & $\begin{array}{l}\text { Syrian rebel groups cut off water supply to Damascus } \\
\text { In August } 2015 \text {, Syrian rebel groups cut off water from a spring in Ain al-Fijah, reducing water } \\
\text { output to Damascus by } 90 \text { percent for three days and leading to water shortages and rationing. } \\
\text { Rebels continue to periodically shut off the supply from the spring, resulting in water shortages } \\
\text { in Ain al-Fijah and Damascus. Rebels threaten to blow up the spring if government forces enter } \\
\text { the region. }\end{array}$ \\
\hline 2015 & $\begin{array}{l}\text { Fallujah, on the Tigris } \\
\text { fter capturing the dam, } \\
\text { s. }\end{array}$ \\
\hline 2015 & $\begin{array}{l}\text { water } \\
\text { Dam, the Islamic } \mathrm{D} \\
\text { tly Shiite downstre }\end{array}$ \\
\hline 2015 & $\begin{array}{l}\text { Attacks interrupt construction of Illisu and Silvan dams, Turkey } \\
\text { At the end of 2014, work on the Ilisu Dam stops for four months after the armed wing of the } \\
\text { Kurdistan Workers' Party (PKK) kidnaps two of the project's subcontractors. When construction } \\
\text { resumes, the largely non-Kurdish workforce is escorted to the site by military tanks. Militants } \\
\text { also target Diyarbakir's Silvan Dam by placing explosives on the roads leading into the site, and } \\
\text { security threats in the region cause construction delays. }\end{array}$ \\
\hline 2015 & $\begin{array}{l}\text { ter flow below Ramadi Dam } \\
\text { (ISIS/ISIL) militants shut off and redirect water flows below Ramadi } \\
\text { ilitary movements across the Euphrates River. As a result, communi- } \\
\text { shortages. }\end{array}$ \\
\hline 2014 & $\begin{array}{l}\text { amic State contaminates drinking water supplies, Syria } \\
\text { deliberately contaminates drinking water with crude oil in the Balad district of the Salahaddin } \\
\text { vernorate. Poisoned water supplies are also reported from Aleppo, Deir ez Zor, Raqqa, and } \\
\text { ghdad. }\end{array}$ \\
\hline 2014 & $\begin{array}{l}\text { Islamic State blocks access to water } \\
\text { In Iraq, Islamic State blocks access to water in the predominantly Christian town of Qaraqosh } \\
\text { (also known as Bakhdida), take over farms and agricultural land, and expel most of the } 50,000 \\
\text { residents. }\end{array}$ \\
\hline
\end{tabular}




\begin{tabular}{|c|c|}
\hline 1 & 2 \\
\hline 2014 & $\begin{array}{l}\text { Islamic State uses Falluja Dam as a weapon } \\
\text { Islamic State closes the Fallujah Dam floodgates and diverts water over an irrigation channel } \\
\text { into a side valley, inundating land up to } 100 \mathrm{~km} \text { away and placing parts of the city of Abu Ghraib } \\
\text { under up to four meters of water. More than } 10,000 \text { houses and } 200 \text { square kilometres of farmland } \\
\text { are flooded and extensive livestock killed. Water for millions of people in the cities of Karbala, } \\
\text { Najaf, and Babil is cut off for a time. }\end{array}$ \\
\hline 2014 & $\begin{array}{l}\text { U.S.-led coalition launches airstrikes to protect dams from ISIS } \\
\text { A U.S.-led coalition launches a series of air strikes against targets of the Islamic State (ISIS/ } \\
\text { ISIL) in areas around Mosul Dam, Fallujah Dam, and Haditha Dam in Iraq. U.S. aircraft destroy } \\
\text { an ISIL-built earthen berm near the Fallujah Dam. This berm was built by ISIL to control down- } \\
\text { stream water supplies and to increase the flow of the Euphrates River into Abu Ghraib canals, } \\
\text { flooding local Shiite neighbourhoods in east Fallujah and forcing the locals to evacuate. }\end{array}$ \\
\hline 2014 & $\begin{array}{l}\text { Syrian government forces are driven out of Wadi Barada's vi } \\
\text { (FSA) cuts off water supply from Ain al-Fijah, a major spring }\end{array}$ \\
\hline 2014 & $\begin{array}{l}\text { Islamic State fighters advance on Haditha Dam } \\
\text { Iraqi officials report that fighters with the Islamic State in Iraq and Syria (ISIS) are advancing on } \\
\text { the Haditha Dam, the second-largest in Iraq, raising the possibility of catastrophic damage and } \\
\text { flooding. The ISIS militants are fighting for control of the Euphrates River dam, about } 120 \text { miles } \\
\text { northwest of Baghdad and government forces were fighting to halt their advance. Army officers } \\
\text { tell employees to stay inside and to be prepared to open the dam's floodgates if ordered to do so, } \\
\text { one employee said }\end{array}$ \\
\hline 2014 & $\begin{array}{l}\text { Insurgents seize Falluja Dam } \\
\text { Insurgents from ISIL (Islamic State in Iraq and the Levant) seize the Falluja Dam in Iraq and close } \\
\text { the floodgates to cause upstream flooding and to cut downstream water supply. The objective is } \\
\text { to flood the area around the city of Falluja to force government troops to retreat and lift a siege, } \\
\text { while cutting water supplies and hydroelectricity generation for other parts of the country. }\end{array}$ \\
\hline $\begin{array}{c}2011- \\
2012\end{array}$ & $\begin{array}{l}\text { al conflict in Syria has been aggravated by the multi-year dro } \\
\text { an } 1.5 \text { million people "mostly farmers and their families" hav } \\
\text { Political unrest began in March } 2011 \text { in Dara'a, and soon es }\end{array}$ \\
\hline
\end{tabular}

Source: http://www.worldwater.org/conflict/list/.

It should be stated that Daesh was the strongest in the period when they ruled over the strategic water infrastructure, above all the Tabqa dam and the Mosul dam. This control allowed Daesh (ISIS) to maintain power in their capital in Iraq, in Mosul, and their capital in Syria, Raqqa (Strategic Foresight, 2019). Although Daesh should no longer pose a threat to water and its infrastructure in Tigris-Euphrates Basin, it should not be ruled out that there will be new non-state Middle East arena actors who will want to re-use the water and its installation to conduct the game, including conflicts. Besides, the authorities of the states of Syria, Iraq, and Turkey may also be subjected to a similar temptation.

Especially in the Arab region water management should be a strategic tool for sustainability and peace (Hefny, 2011: 2). HRH Prince of Jordan Hassan Bin Talal is a leader in water diplomacy in the Middle East. In April 2012 a High-Level Group was established with the HRH as a chairman. However, another war in the Middle East may break out on water resources, because Iraq, Syria, and Turkey defend their claims to two important rivers that flow through this region - Tigris and Euphrates. Turkey's project of Greater Anatolia on the Euphrates-Tigris river basin has had a huge impact on riparian countries. Moreover, conflicts and tensions between countries cause water shortage (NATO, 2007). 
Turkey is trying to implement an ambitious initiative to build 22 power plants there, which can almost halve the flow of water to the countries located downstream of the river, i.e. to Syria and Iraq. The initiative comes from the founder of the modern Turkish state, President Mustafa Kemal Atatürk. For decades, this project has created tension between neighbouring countries, but political quarrels have hindered conversations that enable progress to be made. Ankara claims that he has the right to more water.

The South-Eastern Anatolia Project (GAP) will give Turkey a de facto full control over the waters of the Euphrates and the Tiger. The case of the Euphrates River has long been a contentious issue between Turkey, Syria, and Iraq. This has been the cause of discord for decades. Some say that the South-Eastern Anatolia Project (GAP) would reduce the flow of water flowing from Turkey to Syria, which in turn would have a direct impact on the water arrangements between Syria and Iraq over the Euphrates. There is also tension between Iraq and Iran on the Tigris River and its tributaries. Most of the tributaries of the Tigris in Iraq come from Iran. Iranian development projects in the future may further restrict the flow of these tributaries, which in turn will affect the future for Iraq - both internally and internationally. On the other hand, Iran could decide to supply additional water to Iraq for political reasons only. Transboundary water issues will have a serious turnover when water resources will shrink and populations will multiply. Water may be the cause of conflicts - such as the dispute over the coastal part of Jordan before the 1967 war - and the consequences of the conflict - the destruction of water infrastructure. Additionally, water is also closely related to the peace process and can be an instrument of cooperation (Waslekar, 2011: 60).

Map 2. Map of the South-Eastern Anatolia Project

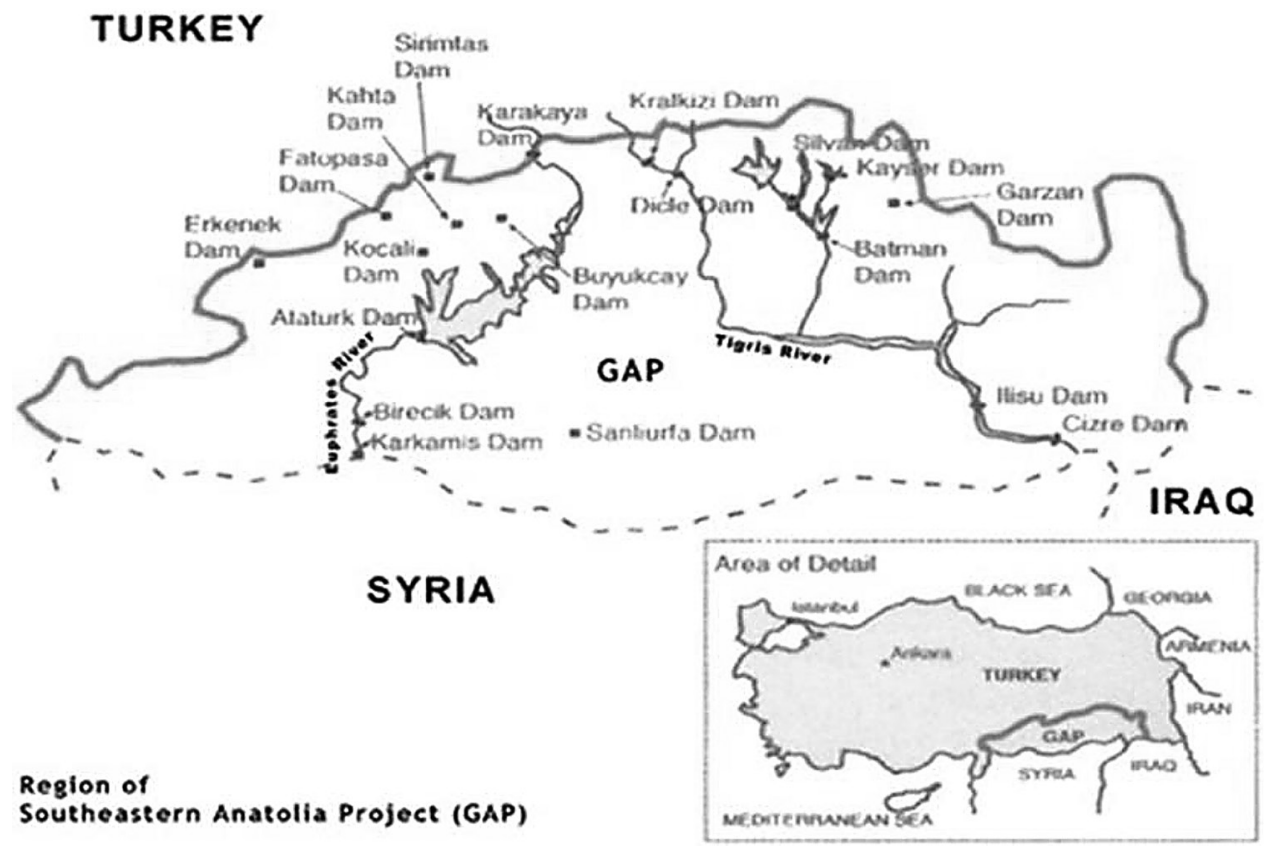

Source: http://expeditieaarde.blogspot.com/2012/02/south-eastern-anatolia-project.html. 
Some researchers suggest that the so-called Arab Spring, which shook the Middle East, took place to some extent because of droughts, which affected the low supply of certain foods and its higher prices. This, in turn, was one of the sources of mass dissatisfaction and protests. So, in the 21 st century, deficiencies will increasingly be the cause of conflicts (Wasinger, 2015: 7). In the coming decades, the water situation in Iraq may be catastrophic. Climate change, rainfall reduction, population growth will have an impact, as well as more and more desertification. The water situation in Iraq will depend, apart from Turkey's policy and more and more from Kurdistan, as well as on Iran because of some Iranian small downstream flows. While, Syria will be dependent on Israel due to the control of the Golan Heights (Cahan, 2017: 178-179).

Some specialists on water from the Middle East underline that this region, as well as the international community, must be engaged in building strong water diplomacy. They stress that it is extremely important to achieve Sustainable Development Goals, as well as an instrument for preventive actions and maintaining durable peace. On 11th of April 2018, during the opening of the MENA's Water Preventive Diplomacy Conference Bahrain's Minister of Electricity and Water Authorities dr. Abdul Hussain bin Ali Mirza underlined that current clashes, conflicts, and instability in the MENA region are larger than other regions. As a reason, he mentioned the fact that more than two-thirds of the region's water resources are flowing from outside, with no binding agreements between the coastal countries (IPI, 2018). The Gulf Cooperation Council (GCC) Secretariat has prepared 'Program of Work for Integrated Management and Sustainable Water Development' underling that water should be one of the major topics of cooperation (Abdelraouf, 2018: 8).

\section{WATER DIPLOMACY}

We cannot reach peace, security and sustainable development without water cooperation. Water is an opportunity for international cooperation, not only in the context of access to fresh water. It is a great chance also in terms of developing sustainable future energy, including hydropower, wave energy, tidal energy, salinity gradient energy, and ocean thermal energy conversion. The International Renewable Energy Agency's (IRENA) in its Medium-term Strategy 2018-2022 has underlined that for the 2030 Agenda for Sustainable Development and the Sustainable Developments Goals, as well as the Paris Agreement on Climate Change since 2015 the international community is trying to achieve sustainable energy as well as the report underline the linkages between renewable energy and international peace and security (IRENA, 2019: 13). As Director-General of the IRENA, Adnan Z. Amin pointed out, it is important that diplomats are looking for ways of reaching the goals of Agenda 2030 (Amin, 2017: 1). Therefore, water diplomacy is crucial for achieving the Sustainable Development Goals (SDG). It is important not just for the 6th aim of SDG associated with water, but for most of them.

For sustainable development, we first need peace, security, and cooperation between nations, countries, and states. According to the Danish Institute of International Studies, in the last 50 years, around 2000 conflicts happened because of water. A cou- 
ple of them were armed conflicts. In the 20th century, many of the wars happened because of oil. In the 21st century, there can be even more wars because of water. In 2003, the Organization for Security and Co-operation in Europe (OSCE) along with the United Nations Development Programme (UNDP), United Nations Environment Programme (UNEP), United Nations Economic Commission for Europe (UNECE), and Regional Environmental Centre for Central and Eastern Europe (REC) have established a cooperation for common facing environment and security challenges as The Environment and Security (ENVSEC) Initiative. This platform takes common actions also on transboundary water basins (OSCE, 2019). Since 2013 the European Union has underlined the need of the EU water diplomacy and its water diplomacy strategy with the aim of conflict prevention. The Foreign Affairs Council during its meeting in July 2013 in a very clear manner has shown the linkages between water with international peace and security. The Council foresees that we can be witnesses over the next decade to more and more tensions and conflicts in the world. This will threaten the foundations of global security (EU, 2013: 1). In 2014, the Organization for Security and Cooperation in Europe (OSCE) has intensified its actions for wider international cooperation using water diplomacy for promoting peace and security, building confidence, as well as conflict prevention. The organization has underlined the significance of water diplomacy as an effective instrument for security and stability (OSCE, 2014: 2) and a key to reach a wider picture of security, sustainability, development and human well-being (OSCE, 2014). It should cover negotiations, mechanisms of prevention and dispute resolution, as well as set up consultation and coordination platforms. In this sense, water should be recognized as a tool for the wider goal of peace and global sustainability development (Schmeier, 2018). For the United Nations as an organization, as well as member states multilateral diplomacy and bilateral efforts should focus on defining sustainable development agenda for the world, and to protect our planet from the effects of climate change (Srivastava, 2014). The United Nations Security Council in 2016, for the first time, organized a discussion on "water, peace, and security." In the meeting have participated 69 states. The UN Secretary General Ban Ki-Moon underlined that from a strategic point of view for global peace and security we need water security. He stressed the destruction of water systems in Syria and Gaza brought about armed conflict (Ban Ki-moon, 2016).

There are too many words about water diplomacy from politics and scientists and too little real coordinated diplomatic actions. International organizations that are key to water diplomacy and the resolution of water conflicts are becoming less and less influential. International law as a fundamental tool for international organizations does not keep up with the challenges. The fundamental international law, UN the most important tool, Convention on the Law of the Non-Navigational Uses of International Watercourses (UN GA, 1997) entered to force in 2014, after 17 years, when it signed. Additionally, 39 states only out of 193 UN members are parties of the Convention. The European Union has called on the international community, including states, international organizations, as well as regional and sub-regional institutions to realize that water diplomacy could face the current challenges, among other things, associated with water, climate change and that contribute to security. Moreover, the European Union for the effectiveness of its water diplomacy called the Council, the European 
Commission, and the High Representative of the Union for Foreign Affairs and Security Policy and member states to coordinate strategies and actions. Additionally, the European External Action Service with the EU Delegations were obliged to intensive actions in the world (EU, 2013).

$$
\text { *** }
$$

In the Tigris-Euphrates basin shared by Iraq, Iran, Syria, and Turkey - yearly groundwater depletion amounts to some thirteen $\mathrm{km}^{3}$, progressively exhausting the basin's reserves. All told, it is likely that replenished overdrafts from aquifers around the world considerably exceed $160 \mathrm{~km}^{3}$ a year, double the annual flow of the Nile (Passarelli, 2015: 147). As a result of this analysis, it should be stated that in the coming years in the Tigris and Euphrates basin cooperation in the framework of hydro policy will be very difficult, which will be affected by difficult relations between various players in the region. These research results are based in some part on the Strategic Foresight Group (SFG) as a regional and global platform for initiatives and projects to treat water as a power for peace. SFG is engaged mainly with the Middle East, Africa and Asia calling for new security architecture based on peace water cooperation. For this purpose, the Strategic Foresight Group set up the Blue Peace Community as a platform for the Middle East with the leadership of HRH Prince Hassan Bin Talal of Jordan. Strategic Foresight Group underlines that water, including its infrastructure, like dams, must be protected against terrorist groups and cannot be a military tool. High-Level Forum in Istanbul pointed out threats connected with controlling Mosul and Haditha Dams and Falluja Dam by Daesh what is the pillar of its military strategy (Strategic Foresight Group, 2015: 17). Extremely important for this research is SFG analyses underlying that any two countries engaged in active water cooperation do not go to war (Motwani, 2017: 3). To build a conclusion, the Swedish International Development Cooperation Agency (SIDA) and the strategy for Sustainable Peace 2017-2022 put the focus on 80 countries and peace building, state building and human security (Government Offices of Sweden, 2017: 2).

Contra Helle Munk Ravnborg from the Danish Institute of International Studies says that there will be less of transboundary water conflicts because of cooperation and joint projects. Moreover, the analysis in this paper indicates that water tensions will happen more often. Lawrence Susskind, Shafiqul Islam in the book "Water Diplomacy: A Negotiated Approach to Managing Complex Water Networks" (New York, 2013) underline a need for effective "Water Diplomacy Framework" (WDF) and Water-Diplomacy Network (WDN), as well as Global Water Partnership. There is an interesting concept of A Hydropolitical Security Complex by Schulz that needs further research. He points out geopolitics and showing the rivers in the context of national security, as crucial parts of securities strategies. This research results in a focus on anarchic structures and national interests. Limitations of the research are large initiatives and not possible to present all of them in the article.

The current global Westphalian architecture tries to enclose the anarchic nature of the world by ordering a large network of international law and international organizations. But political and economic dynamic processes with the concepts of hegemony 
and structures based on nation states with national interests are in clashes and tensions with each other. New emerging global security architecture is at the top challenge for contemporary diplomacy. In the current world, we have a crisis of global order with a new division of zones of influence. Due to a lack of adaptation a global system to emerging new balance of power, world order experiences crisis. It is concluded that global diplomacy could be very active coordinators of initiatives to face challenges associated with water and climate change, which has a direct impact on security at many levels, including global security architecture, as well as the economy, innovative strategies. So, water diplomacy is crucial for sustainable development and emerging new international system and diplomacy. Water diplomacy as a global dynamic process can build a new model of international cooperation, creating network efficiency of global governance for future challenges and to achieve most of the Sustainable Development Goals. It is a new concept of diplomacy. Water significance is growing for international relations, strategies, geopolitics and rapid changes in many areas of human activities. Water like an essential part of any organism is a fundamental part of international life, connecting different fields of cooperation.

Water has a wider and deeper meaning, as a political concept with higher geopolitical, international strategic significance and security consequences. In the future, due to rising world inequality, it will have a large impact on global security architecture (Y1ldiz, 2015: 4). The United States' Office of the Director of National Intelligence in February 2012 released a paper underling that for 10 years many key countries to the US will face instability, increasing regional tensions, as well state failure. The reason for that situation will provide a challenge related to water. Moreover, the Office of the Director of National Intelligence stresses that that water must be a key to maintaining the national interests of the US. Additionally, by full global engagement in solving water challenges, the US will increase its global influence (Leight, 2012: 2).

The key challenge for achieving peace is the inability to act with the complexity and uncertainty associated with conflicts and cooperation over common water resources (Huntjens, de Man, 2017: 10). To resolve water challenges, we need coordinated actions at the political global level. We have a lot of regional and global initiatives, like UN-Water, UNDP, the UNECE Water Convention, UNESCO, UNEP, Green Diplomacy Network, G-7, G-20 with too much fragmentation. On our planet, we need global coordination with a clear vision and strong leadership in multilateralism with a focus on having regard for the constellation of national interests. Water as an international, indispensable, and emotional topic should be a foundation for confidence building and peace (Cuppari, 2017: 1). But the real world is much more complicated, with an unlimited number of factors influencing policy making at all levels (Bo Kjellén, 2004: 109).

The regionalization and fragmentation of the global security architecture follow each nation's focus on the implementation of national interests. Water diplomacy as a network with many stakeholders does not have effective coordination. Moreover, in emerging global security architecture there will be a larger focus on national interests. This global security architecture will be based on world division and chaos. An emerging new global security architecture will not serve for water diplomacy. Instead, a new model of diplomacy will serve global corporations. Water diplomacy and new 
technology will make stakeholders interested in selling new technology for business purposes and to realize national and global corporations' interests. Future anarchical global security architecture will lead to a hegemonic system of water relations.

\section{REFERENCES}

Abdelraouf M. (2018), West Asia Regional Cooperation on Water and Sustainable Development Goal 6, "EDA Insight", October, http://eda.ac.ae/docs/default-source/Publications/eda-insight_wa-water-diplomacy_en_final.pdf?sfvrsn=2.

Amin A. (2017), The Age of Renewable Energy Diplomacy, "EDA Reflection", October, http:// eda.ac.ae/docs/default-source/Publications/eda_reflection_age_of_renewable_energy_ en.pdf? sfvrsn=2.

Ban Ki-moon (2016), Remarks to Security Council debate on Water, Peace and Security, United Nations Secretary General, 22.11.2016, https://www.un.org/sg/en/content/sg/speeches/201611-22.

Cahan J. (ed.) (2017), Water Security in the Middle East, "Essays in Scientific and Social Cooperation", Publisher: Anthem Press, Series: Anthem Water Diplomacy Series.

Cleveland C. (2010), China's Monster Three Gorges Dam is About To Slow The Rotation Of The Earth, "Business Insider", June 18, https:/www.businessinsider.com/chinas-three-gorgesdam-really-will-slow-the-earths-rotation-2010-6.

Cuppari R. (2017), Water Diplomacy, International Centre for Water Resources and Global Change, Policy Brief Number 1/2017, http://www.waterandchange.org/wp-content/uploads/2017/06/ PB_WaterDiplomacy_lowres.pdf.

David M., Passarelli R. (2015), Conflict Basins: Powderkegs to Paecepipes, “SAIS Review”, Vol. 35, No. 1, Winter-Spring.

Deen T. (2014), U.N. Decries Water as Weapon of War in Military Conflicts, United Nations, IPS, May 19, http://www.ipsnews.net/2014/05/u-n-decries-water-as-weapon-of-war-in-militaryconflicts/.

EU (2013), Council Conclusions on EU Water Diplomacy, Foreign Affairs Council, Brussels, 22 July, http://www.europarl.europa.eu/meetdocs/2009_2014/documents/droi/dv/1407_ councilconclusions_/1407_councilconclusions_en.pdf.

Government Offices of Sweden, Ministry of Foreign Affairs, Strategy for Sustainable Peace 2017-2022, https://www.government.se/490051/globalassets/government/block/fakta-ochgenvagsblock/utrikesdepartementet/sanktioner/strategi-hallbar-fred-eng-slutlig.pdf.

Handy N. (2011), Turkey's Shifting Relations with its Middle East Neighbors during the Davutoğlu Era: History, Power and Policy, Bilgi (23), Yaz.

Hefny M. (2011), Water Diplomacy: A Tool for Enhancing Water Peace and Sustainability in the Arab Region, "Technical Document", Cairo, November, http:/www.unesco.org/new/ fileadmin/MULTIMEDIA/FIELD/Cairo/Water\%20Diplomacy\%20in\%20Action\%20 Strategy\%20Doc\%203\%20Rev\%202\%20Final\%20and\%20Action\%20Plan\%5B1\%5D.pdf.

Huntjens P., de Man R. (2017), Water diplomacy: Making water cooperation work, The Hague Institute Policy Brief, April, https://www.planetarysecurityinitiative.org/sites/default/files/201704/PB_Water_Diplomacy_WG_4.pdf.

IPI (2018), Experts Call for Preventive “Water Diplomacy” in the MENA Region, (April 11), https:// www.ipinst.org/2018/04/preventive-water-diplomacy-mena-region\#4. 
IRENA (2018), Medium-term Strategy 2018-2022, Report of the Director-General of the International Renewable Energy Agency, Eighth session of the Assembly, Abu Dhabi, 13-14 January, https://www.irena.org/-/media/Files/IRENA/Agency/About-IRENA/Assembly/EighthAssembly/A_8_11_MTS-2018-2022.pdf?la=en\&hash=07546C5D6CB968EEEDBEBE322 136DEF2AB389AFB.

Kamphof R., Melissen J. (2018), Foreign Ministries, SDG Diplomacy and the Private Sector, SWP Working Paper No. 22, April, https://www.swp-berlin.org/fileadmin/contents/products/ arbeitspapiere/WP_Diplomacy21_No22_Kamphof_Melissen.pdf.

Kibaroglu A. (2017), State-of-the-art review of transboundary water governance in the Euphrates Tigris river basin, "International Journal of Water Resources Development", 07 Dec, https:// aquadoc.typepad.com/files/review_tb_water_governance_euphrates_tigris.pdf.

Kibaroglu A. (2015), Transboundary Water Governance in the Euphrates Tigris River Basin, "EInternational Relations", Jul 22, https://www.e-ir.info/2015/07/22/transboundary-water-governance-in-the-euphrates-tigris-river-basin/.

Kibaroglu A. et al. (2011), Turkey's Water Policy, DOI 10.1007/978-3-642-19636-2_16, \# Springer-Verlag Berlin Heidelberg 2011, https://www.iraqicivilsociety.org//wp-content/uploads/ 2013/02/Kibaroglu-scheumann-euphrates-tigris-river-system.pdf.

Kjellén B. (2004), Pathways to the Future: The New Diplomacy for Sustainable Development, "IDS Bulletin" 35(3): 107-113, DOI 10.1111/j.1759-5436.2004.tb00143.x.

Leight N. (2012), Water \& Public Diplomacy, “Policy Brief”, April, https://www.uscpublicdiplomacy.org/sites/uscpublicdiplomacy.org/files/useruploads/u22281/Water_Diplomacy_Policy_Brief_Online.pdf.

Menga F. (2016), Domestic and International dimensions of transboundary water politics, "Water Alternatives", Vol. 9 (3), http://www.water-alternatives.org/index.php/alldoc/articles/vo19/ v9issue3/322-a9-3-17/file.

Motwani P. R. (2017), Water Cooperation Quotient, Strategic Foresight Group, Mumbai, https:// www.strategicforesight.com/publication_pdf/Water\%20Cooperation\%20Quotient\%202017. pdf.

OSCE (2014), Enhancing security through water diplomacy: The role of the OSCE, OSCE, Hofburg, 8 July, (SEC.DAYS/9/14/Rev.1), https://www.osce.org/sg/120018?download=true.

OSCE (2019), Environment and Security, (ENVSEC) Initiative, (07/04/2019), https://www.osce.org/ secretariat/ENVSEC.

OSCE (2014), Water diplomacy, 1 July, https://www.osce.org/sg/120614.

Pacific Institute (2019), Water Conflict Chronology, Pacific Institute, Oakland, CA. (27.08.2019), https://www.worldwater.org/water-conflict/.

Scheumann W., Shamaly O. (2016), The Turkish-Syrian Friendship Dam on the Orontes River: Benefits for All?, in: Water Resources Management in the Lower Asi-Orontes River Basin: Issues and Opportunities, Graduate Institute of International and Development Studies; Istanbul, MEF University, Geneva, https:/docs.water-security.org/files/e\%20Documents/ Lower\%20Asi\%20Orontes\%202016/Chapter_12.pdf.

Schmeie S. (2018), What is Water Diplomacy and Why Should You Care?, "Global Water Forum", August 31, http://www.globalwaterforum.org/2018/08/31/what-is-water-diplomacy-andwhy-should-you-care/.

SFG (2011), Blue Peace: Rethinking Middle East Water, Strategic Foresight Group, Mumbai, https:// www.eda.admin.ch/dam/deza/en/documents/publikationen/Diverses/198458-the-bluepeace_EN.pdf. 
SFG (2015), Blue Peace: Rethinking Middle East Water, Strategic Foresight Group, Mumbai, https:// www.strategicforesight.com/publication_pdf/28458Lessons\%20Learnt.pdf.

SFG (2019), The Blue Strike List in the Middle East, "Blue Peace Bulletin", Vol 3, https://www. strategicforesight.com/publication_pdf/Blue\%20Strike\%20List.pdf.

SFG (2017), Water Cooperation Quotient, Strategic Foresight Group, Mumbai, https://www.strategicforesight.com/publication_pdf/Water\%20Cooperation\%20Quotient\%202017.pdf.

Srivastava L. (2014), Strengthening Multilateral Diplomacy and Sustainable Development, "The Magazine of the United Nations", Vol. LI, No. 3, https:/unchronicle.un.org/article/strengthening-multilateral-diplomacy-and-sustainable-development.

Susskind L., Shafiqul I. (2012), Water Diplomacy: Creating Value and Building Trust in Transboundary Water Negotiations, "Science \& Diplomacy", Vol. 1, No. 3, September, http://www. sciencediplomacy.org/files/water_diplomacy_science_diplomacy.pdf.

UN (2018), High-Level Panel on Water Diplomacy, Deputy Secretary-General's remarks, Stockholm (August 27), https://www.un.org/sg/en/content/dsg/statement/2018-08-27/deputy-secretarygenerals-remarks-high-level-panel-water-diplomacy.

UN (2014), Strengthening Multilateral Diplomacy and Sustainable Development, "The Magazine of the United Nations" Vol. LI, No. 3, https://unchronicle.un.org/article/strengthening-multilateral-diplomacy-and-sustainable-development.

UNWATER (2018), Nature-Based Solutions for Water, "World Water Development Report", 19 March, http://www.unwater.org/world-water-development-report-2018-nature-basedsolutions-for-water/.

Wasinger C. (2015), Peace Be Dammed? Water Power and Water Politics in the Tigris-Euphrates Basin, Bowdoin College Bowdoin Digital Commons Honors Projects 5-2015.

Waslekar S. (2011), Blue Peace: Rethinking Middle East Water, Strategic Foresight Group, https:// www.eda.admin.ch/dam/deza/en/documents/publikationen/Diverses/198458-the-bluepeace_EN.pdf.

Wirsing R., Jasparro C. (2007), River rivalry: Water disputes, resource insecurity and diplomatic deadlock in South Asia, "Water Policy" 9 (3), https://doi.org/10.2166/wp.2007.014.

Y1ld1z D. (2015), Water and H2O Difference in Terms of International Relationship, "World Scientific News" 10, www.worldscientificnews.com.

Zhupankhan A., Tussupova K., Berndtsson R. (2017), Could Changing Relationships Lead to Better Water Sharing in Central Asia?, "Water" 9 (20 February).

\begin{abstract}
The paper aims to present water as a weapon of war in the Tigris-Euphrates Basin, as well as the role and significance of water for a new architecture of global security. The main goal of the study is to find an answer to the research question of whether water the Tigris-Euphrates Basin will be still a tool for fighting or cooperation as an effective tool for facing strategic challenges. The research hypothesis is that the issue of challenges related to water in the Euphrates River basin will, first of all, follow the social and political-economic relations between Turkey, Iraq and Syria and external factors. The research was conducted using a descriptive-analytical method. Moreover, this research is based on the neorealist theory of international relations, and the concept of international constellation analysis, as well as the theory of neo-institutionalism.

Future anarchical global security architecture will lead to a hegemonic system of water relations. Therefore, without international coordination and far-reaching strategy in the face of
\end{abstract}


the emerging anarchic global security structure, stable water cooperation in this region cannot be reached.

Keywords: water diplomacy, sustainable development goals, global security architecture

\section{WODA JAKO NARZACDZIE WOJNY W BASENIE TYGRYSU-EUFRATU}

\section{STRESZCZENIE}

Artykuł ma na celu przedstawienie wody, jako broni używanej w wojnie w basenie rzek Tygrysu i Eufratu, a także roli i znaczenia wody dla nowej architektury globalnego bezpieczeństwa. Głównym celem jest znalezienie odpowiedzi na pytanie badawcze, czy woda w basenie Tygrysu i Eufratu będzie nadal narzędziem walki, czy współpracy, jako skuteczne narzędzie do sprostania wyzwaniom strategicznym. Hipotezą jest stwierdzenie, że wyzwania związane z wodą w dorzeczu Eufratu i Tygrysu będzie przede wszystkim podążać za stosunkami społecznymi i polityczno-gospodarczymi pomiędzy Turcją, Irakiem i Syrią oraz czynnikami zewnętrznymi. Badania przeprowadzono metodą opisowo-analityczną. Ponadto badania oparto na neorealistycznej teorii stosunków międzynarodowych oraz koncepcji międzynarodowej analizy konstelacji, a także teorii neoinstytucjonalizmu.

Przyszła anarchiczna globalna architektura bezpieczeństwa doprowadzi do hegemonicznego systemu stosunków wodnych. Dlatego też, bez międzynarodowej koordynacji i dalekosiężnej strategii w obliczu pojawiającej się anarchicznej globalnej struktury bezpieczeństwa, stabilna współpraca wodna w tym regionie nie jest możliwa.

Słowa kluczowe: dyplomacja wodna, cele zrównoważonego rozwoju, globalna architektura bezpieczeństwa 